Article

\title{
Single-step conversion of lignin monomers to phenol: Bridging the gap between lignin and high-value chemicals
}

\author{
Jiaguang Zhang a,b,†, Loris Lombardo a,c,t, Gökalp Gözaydın a, Paul J. Dyson c, Ning Yan a,* \\ a Department of Chemical and Biomolecular Engineering, National University of Singapore, 117585 Singapore \\ b School of Chemistry, University of Lincoln, Joseph Banks Laboratories, Green Lane, Lincoln, LN6 7DL, United Kingdom \\ c Institute of Chemical Sciences and Engineering, Ecole Polytechnique Fédérale de Lausanne (EPFL), CH-1015, Switzerland
}

\section{A R T I C L E I N F}

\section{Article history:}

Received 28 June 2018

Accepted 4 July 2018

Published 5 September 2018

\section{Keywords:}

Lignin

Phenol

Zeolite

De-alkylation

Hydro-demethoxylation

\begin{abstract}
A B S T R A C T
Transformation of lignin into high-value chemicals is hampered by the complexity of monomers obtained from lignin depolymerization. Here we report a strategy, composed of hydro-demethoxylation and de-alkylation reactions, that is able to chemically converge various lignin-derived phenolic monomers into phenol in a single-step. Using 2-methoxy-4-propylphenol as a model compound, Pt/C exhibited the best performance in hydro-demethoxylation reaction affording $>80 \%$ 4-propylphenol from 2-methoxy-4-propylphenol, while H-ZSM-5 was identified as the most suitable catalyst for de-alkylation, achieving 83\% yield of phenol from 4-propylphenol. Since the two catalysts operate under compatible conditions, combining the two catalysts to simultaneously promote both hydro-demethoxylation and de-alkylation reactions was achieved. Configuration of how to organize the catalysts is a critical parameter, where the physical mixture of the two was most effective, providing over 60\% phenol from 2-methoxy-4-propylphenol in a single-step.
\end{abstract}

(C) 2018, Dalian Institute of Chemical Physics, Chinese Academy of Sciences. Published by Elsevier B.V. All rights reserved.

\section{Introduction}

Lignin, a main component of lignocellulosic biomass accounting for $15 \%-30 \%$ by weight and $40 \%$ by energy $[1,2]$, is still not sufficiently used in biorefineries. Despite the significant advances in lignin depolymerisation via hydrogenolysis [3-21], oxidation [22-27], hydrolysis [28-34], thermal [35-37], photo[38-40] and electro-chemical [41] transformations in the past decade, the depolymerized lignin is most often a complex mixture of phenolic compounds hampering direct use as high-value chemicals. This is first of all attributed to the non-uniform nature of lignin. Unlike cellulose [42] and chitin [43], the top two biopolymers in nature-that contain only one monomer linking together primarily by 1,4-glycosidic bond in a liner form, lignin is composed of three types of substituted phenols connected by a number of $\mathrm{C}-\mathrm{O}$ and $\mathrm{C}-\mathrm{C}$ bonds, forming a three-dimensional amorphous, irregular polymer. Second, lignin polymers may undergo non-selective fragmentation and rearrangement during depolymerisation [13], further complicating the product stream.

One solution to the problem is to produce lignin with a simpler structure via generic engineering. For instance, overexpression of the ferulate 5-hydroxylase gene in poplar (Populus spp.) affords lignin with almost pure syringyl units and close to $90 \% \beta-0-4$ linkages [4]. Nevertheless, this technique is currently not widely applied and its economic viability remains to be seen. Another solution is to develop strategies that are able to converge complex monomers derived from lignin into a sin-

\footnotetext{
* Corresponding author. E-mail: ning.yan@nus.edu.sg

† These authors contributed equally to this work.

This work was supported by the Ministry of Education in Singapore Tier-1 (R-279-000-479-112) and Tier-2 (R-279-000-462-112) Projects. DOI: 10.1016/S1872-2067(18)63132-8 | http://www.sciencedirect.com/science/journal/18722067 | Chin. J. Catal., Vol. 39, No. 9, September 2018
} 
gle stream. An elegant biological funnelling strategy was proposed and developed, in which a lignin liquor stream was converted to polyhydroxyl acid, forming the foundation of various end uses [44]. As far as we are aware, one-step chemical transformation that convert, or conceptually that are able to convert, lignin derived monomer mixtures such as 2-methoxy-4-propylphenol and 2,6-dimethoxy-4-propylphenol into a single value-added product is very rare.

Despite the complexity of decomposed lignin, the structures of the products are not without patterns. A common feature for the monomers obtained from lignin under neutral or reductive conditions is that they are substituted phenols bearing zero to two methoxyl groups in the ortho-position and an alkyl group in the para-position. If highly selective de-methoxyl [45-53] and de-alkyl [54-61] chemistry could simultaneously occur, one may anticipate that a mixture of substituted phenols to be converted into a single-compound phenol (Scheme 1). Notably, phenol is one of the most important aromatic chemicals utilized in industry reaching an annual production of 8.9 million tons [51], mainly used as synthetic polymer precursors such as bisphenol-A and nylon [62,63], as well as pharmaceuticals and herbicides. Its current production is mainly through the Hock Process based on petroleum feedstock, including oxidation of cumene with oxygen and then cleavage of the cumene peroxide formed in the first step to afford phenol and acetone in a 1:1 ratio [62]. One disadvantage of the process, among others, is that the demand for phenol far exceeds the demand for acetone. Previously, converting alkyl phenols into phenol has been reported, but the substrates are limited to non-methoxyl group containing ones [54-58].

In this work, we developed a single-step route to convert lignin derived monomers into phenol using 2-methoxy-4-propylphenol as a model compound. To identify proper catalyst combination, we first optimized 2-methoxy-4-propylphenol conversion into 4-propylphenol over noble metal catalysts in the presence of hydrogen. Then de-alkylation of 4-propylphenol into phenol was evaluated and optimized using zeolite catalysts. We further demonstrated a single-step protocol to convert 2-methoxy-4-propylphenol into phenol, by physical mixing Pt/C and H-ZSM- 5 catalysts. Catalyst screening, reaction condition optimization, effect of water, as well as the effect of the way to mix the two catalysts in single-step conversion were studied. We also studied the deactivation mechanism for de-alkylation, and propose possible ways to regenerate the catalysts.

\section{Experimental}

Technical grade $\mathrm{H}_{2}$ (99.99\%), forming gas $\left(20 \% \mathrm{H}_{2}\right)$, nitrogen (99.99\%), air $\left(21 \% \pm 1 \% \mathrm{O}_{2}\right)$, CO (99.8\%) were acquired from Air Liquide. 2-methoxy-4-propylphenol ( $\geq 99 \%)$, 4-propylguaiacol ( $\geq 99 \%)$, 4-propylphenol ( $\geq 97 \%)$, platinum on carbon (5 wt \%), platinum on silica (1 wt\%), platinum on alumina (5 wt\%), palladium on carbon (10 wt\%) were purchased from Sigma-Aldrich. H-ZSM-5 $\left(\mathrm{SiO}_{2} / \mathrm{Al}_{2} \mathrm{O}_{3}=25\right)$, HUSY $\left(\mathrm{SiO}_{2} / \mathrm{Al}_{2} \mathrm{O}_{3}=14\right)$, and beta zeolite $\left(\mathrm{SiO}_{2} / \mathrm{Al}_{2} \mathrm{O}_{3}=25\right)$ were obtained from the Catalyst Plant of Nankai University. Dichloro-

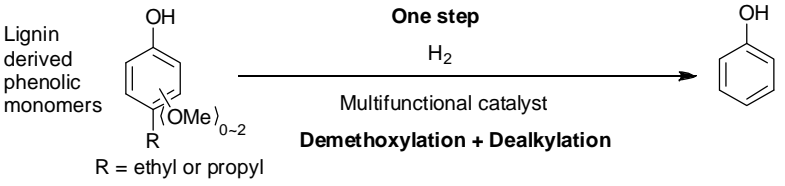

Scheme 1. The strategy to truncate lignin derived phenolic monomers to phenol, together with methanol and alkenes as valuable side-products.

methane (HPLC grade) and ethanol (HPLC grade) were from VWR Chemicals. Multiwall carbon nanotubes (MWCNT) (ø: 20-40 nm; 70-120 $\mathrm{m}^{2} / \mathrm{g}$ ) were purchased from Shenzhen Nanotech Port Co., Ltd. $\mathrm{Pt}_{1} / m-\mathrm{Al}_{2} \mathrm{O}_{3}$ [64], 5 wt\% Pt/MWCNT [65] and Mn-P-ZSM-5 [55] were prepared following literature methods. In the above, $\mathrm{Pt}_{1}$ refers to the single-atom identify of Pt species, whereas $m-\mathrm{Al}_{2} \mathrm{O}_{3}$ stands for mesoporous alumina [64].

\subsection{Hydro-demethoxylation}

In a typical experiment, 2-methoxy-4-propylphenol was injected at a defined flow rate by a syringe pump (Harvard Appartus, PHD 2000 Infusion, or LongerPump, LSP04-1A) into a stainless steel reactor tube (outer diameter of $10 \mathrm{~mm}$ ) containing the catalyst. The catalyst was fixed in the middle of the reactor tube using silica wool. Hydrogen gas or a mixture of hydrogen/nitrogen gas was delivered to the tubular reactor at a precise flow rate by using a mass flow controller. The liquid products were trapped by bubbling through ice-water cooled DCM (25 mL), and then analyzed by GC-FID and GC-MS techniques. The reactant conversion and product yield were determined using dodecane as an internal standard. Several catalysts were tested under different reaction conditions by changing the temperature, the gas composition, gas and substrate flow rate, as well as catalyst amount.

\subsection{De-alkylation}

For the de-alkylation of propylphenol, the same stainless steel tubular reactor as the hydro-demethoxylation reaction was employed. Zeolite catalysts were tested and placed in the middle of the furnace. Substrate and water were fed by using two syringe pumps (Harvard Appartus, PHD 2000 Infusion, and LongerPump, LSP04-1A). A mass flow controller was again used to control the flow rate of the gas (hydrogen/nitrogen mixture with $20 \%$ hydrogen, nitrogen or purified hydrogen). Products were trapped by bubbling through ice-water cooled DCM (25 mL) and analyzed by GC-FID or GC-MS using dodecane as an internal standard.

\subsection{Combined hydro-demethoxylation and de-alkylation reactions}

Combined reactions were conducted in a similar manner as that described for hydro-demethoxylation and de-alkylation reactions. The major difference is that the two catalysts were mixed using different configurations inside the reactor, as provided in Section 3.3. 


\subsection{Analysis methods}

GC-FID (Agilent 7890A) equipped with an HP-5 capillary column $(30 \mathrm{~m} \times 250 \mu \mathrm{m})$ was used to quantify the products. GC-MS (Agilent 7890A) was used to determined side products of hydro-demethoxylation and de-alkylation reactions. Thermogravimetric analyses (TGA) were performed on Shimadzu DTG-60A. BET (Nova) was employed to determine the pore volume of fresh and used H-ZSM-5. Fourier Transform infrared spectroscopy (FTIR) was carried out on a Bio-Rad Vertex 70.

\section{Results and discussion}

\subsection{Hydro-demethoxylation reaction}

The hydro-demethoxylation was carried out using 2-methoxy-4-propylphenol as a model compound in a stainless steel tubular flow reactor at $400^{\circ} \mathrm{C}$, using Pt/C, Pd/C and $\mathrm{Ru} / \mathrm{C}$ catalysts, respectively. The system requires some time to reach steady state so that the substrate conversion and 4-propylphenol selectivity during the second hour were compared (Fig. 1). Active carbon alone was inert, while the three metal catalysts exhibited distinctively different activities. Pt/C was most active (70\% conversion), followed by $\mathrm{Ru} / \mathrm{C}(55 \%$ conversion) and $\mathrm{Pd} / \mathrm{C}(<15 \%$ conversion). $\mathrm{Pt} / \mathrm{C}$ was also the most selective catalyst, enabling $>95 \%$ selectivity towards 4-propylphenol. The main side products as observed by GC-MS analysis include 4-propylcresol, 4-propylcatechol, 4-propylbenzene and benzene.

Other Pt catalysts, including Pt supported on $\mathrm{Al}_{2} \mathrm{O}_{3}$, mesoporous $\mathrm{Al}_{2} \mathrm{O}_{3}\left(m-\mathrm{Al}_{2} \mathrm{O}_{3}\right), \mathrm{SiO}_{2}$, and MWCNT, were tested to determine the effect of support in hydro-demethoxylation reaction. Surprisingly, no or small formation of product was ob-
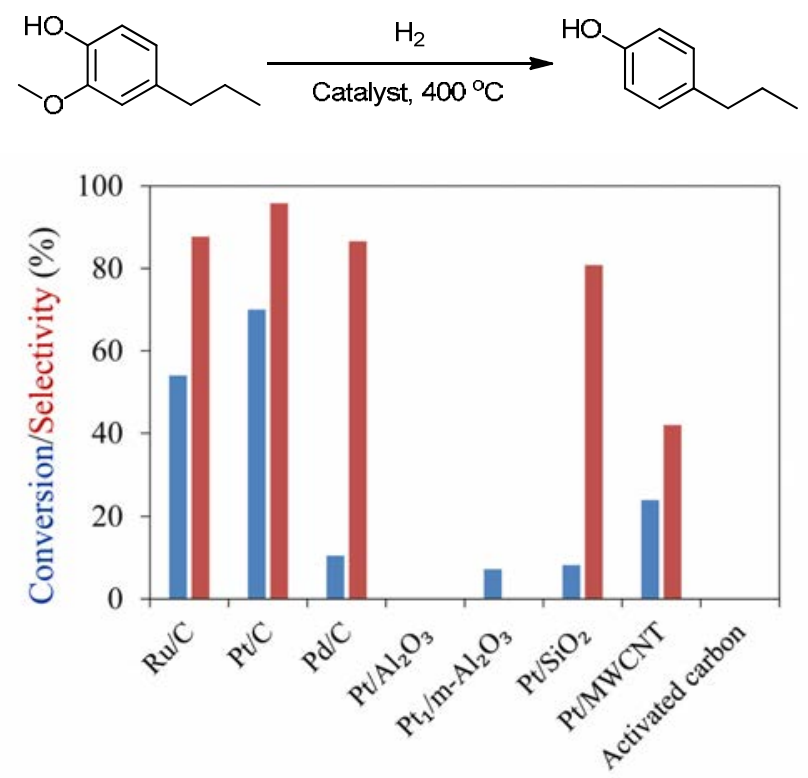

Fig. 1. Catalyst screening for hydro-demethoxylation of 2-methoxy-4-propyl phenol. Reaction conditions: catalyst $75 \mathrm{mg}, 400$ ${ }^{\circ} \mathrm{C}$, 2-methoxy-4-propylphenol injection rate $3.01 \mathrm{mmol} / \mathrm{h}, \mathrm{H}_{2}$ flow rate $20 \mathrm{ml} / \mathrm{min}$. The data shown above are based on GC analysis of the sample collected on stream for $1 \mathrm{~h}$ from the second hour onwards. served for the alumina and silica supports, while MWCNT was the second best support providing 20\% 4-propylphenol. It appears that the interaction between 2-methoxy-4-propylphenol and the support is a key factor to initiate the reaction. Activated carbon and MWCNT both have a porous structure with a small amount of chemically bounded oxygen. The existence of both hydrophobic carbon and hydrophilic oxygen regions plausibly provide strong interactions with the substrate featuring a benzene ring that is hydrophobic, as well as hydroxyl and methoxyl groups that are hydrophilic. The larger surface area of activated carbon $\left(>1000 \mathrm{~m}^{2} / \mathrm{g}\right.$ ) may be the reason for its superior performance compared with MWCNT support which has a surface area of only $80 \mathrm{~m}^{2} / \mathrm{g}$ [66].

Further efforts to optimize the Pt/C catalyst were made. One important parameter in flow rate reactions is the contact time between catalyst and substrate, given by the weight-to-feed ratio $(W / F$, mass of catalyst over mass flow rate). We evaluated a series of $W / F$ values, ranging from 0.1 to $0.25 \mathrm{~h}$, by changing the loading of Pt/C catalyst (Fig. S1). Not unexpectedly, the conversion tends to increase with the increase of $W / F$, at an expense of decreased selectivity to 4-propylphenol. A $W / F$ of $0.15 \mathrm{~h}$ was the best compromise between conversion and selectivity, at which point $84 \%$ conversion and $94 \%$ selectivity were achieved, providing a 4-propylphenol yield of ca. $80 \%$. A time on stream study was conducted at $350{ }^{\circ} \mathrm{C}$, purposely selected to have a lower initial conversion than that obtained at $400{ }^{\circ} \mathrm{C}$ (Fig. S2). As can be seen, conversion and selectivity increased during the first $2 \mathrm{~h}$ and stabilized thereafter. Encouragingly, there was no sign of deactivation under the applied conditions for at least $4 \mathrm{~h}$. The reaction could also be conducted in a batch reactor at slighter lower temperature. Other substrates, including 2-methoxy-4-ethylphenol and 4-methyl-2,6-dimethoxyphenol, were converted into $20 \%-50 \%$ alkylphenol under non-optimized conditions, suggesting that the catalytic system developed is applicable to other types of lignin monomers and should be applicable to convert a mixture of lignin monomers (Table S1).

\subsection{De-alkylation of alkylphenol to phenol}

De-alkylation reaction has been widely investigated for substituted benzene. Ethyl and propyl benzene readily undergo de-alkylation in gas phase on zeolites such as Re/ZSM-5 [67]. The zeolite pore volume is the key parameter for the selectivity and conversion of alkylbenzenes to benzene. On the other side, de-alkylation of substituted phenols into phenol remains hardly investigated. As we are aware, there were only a couple of reports describing the process, where 4-ethyl phenol was converted to phenol and ethylene over ZSM-5 zeolite catalyst [55]. The system is only active for para-substituted phenols, while ortho- or meta-ethyl phenols were not convertible because they cannot diffuse into the zeolite pores due to their larger molecular sizes. In a recent study, Sels et al. [54] reported the excellent de-alkylation performance of alkylphenols using a simple acidic H-ZSM-5 zeolite as catalyst. They found that co-feeding water is crucial to avoid fast catalytic deactivation and to obtain good selectivity. 

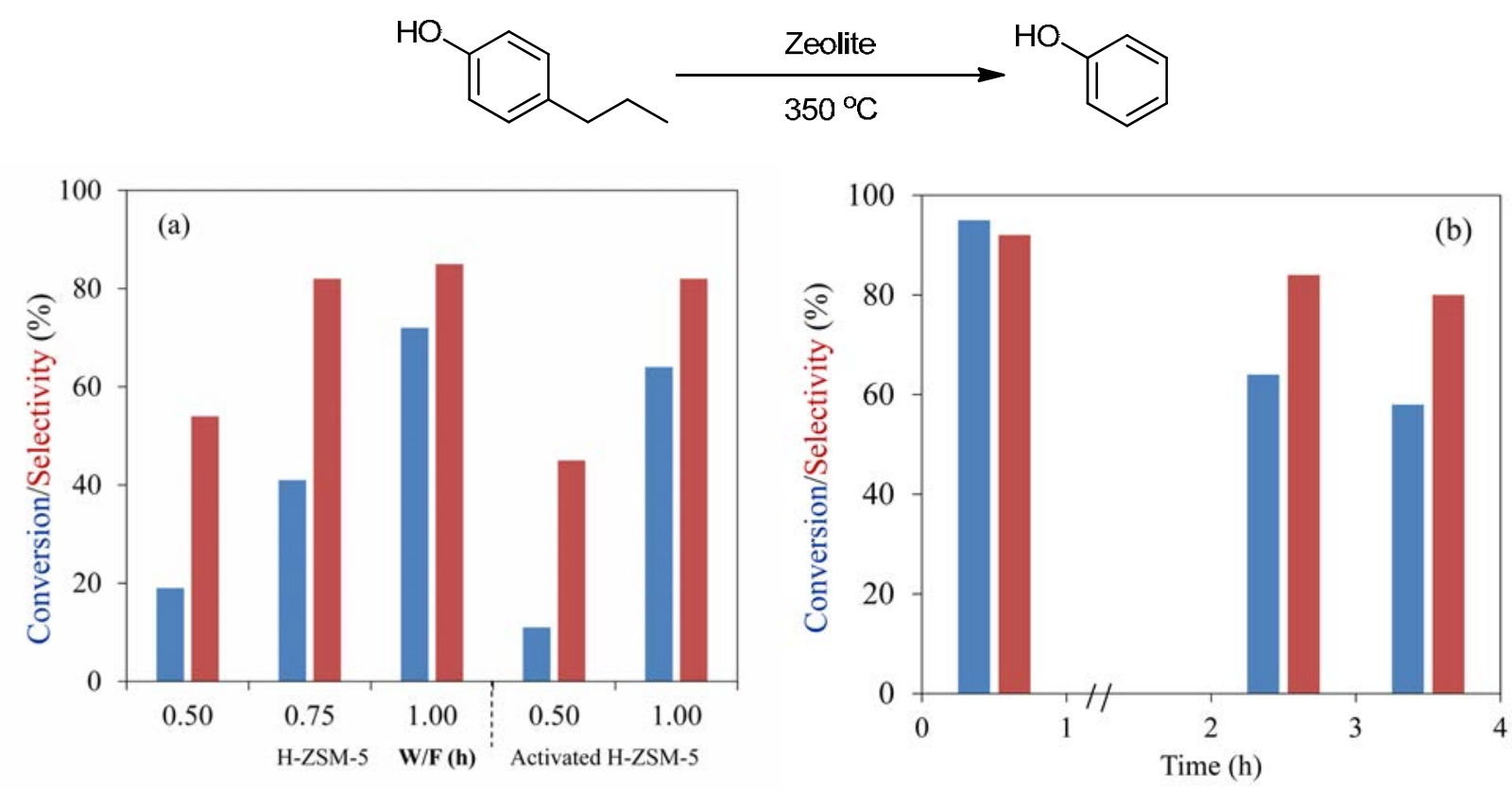

Fig. 2. De-alkylation of 4-propylphenol. (a) Effect of catalyst loading and catalyst activation. Reaction conditions: varied amount of un-activated or activated $\mathrm{H}-\mathrm{ZSM}-5,350{ }^{\circ} \mathrm{C}$, 4-propylphenol infusion rate $240 \mu \mathrm{L} / \mathrm{h}$, water infusion rate $180 \mu \mathrm{L} / \mathrm{h}, 20 / 80 \mathrm{H}_{2} / \mathrm{N}_{2}$ flow rate $50 \mathrm{~mL} / \mathrm{min}$. The data shown above are based on GC analysis of the sample collected on stream for $1 \mathrm{~h}$ from the second hour onwards. (b) Effect of time on stream. Reaction conditions: H-ZSM-5 $200 \mathrm{mg}, 350{ }^{\circ} \mathrm{C}$, 4-propylphenol infusion rate $240 \mu \mathrm{L} / \mathrm{h}$, water injection rate $180 \mu \mathrm{L} / \mathrm{h}, 20 / 80 \mathrm{H} / 2 \mathrm{~N}_{2}$ flow rate $50 \mathrm{~mL} / \mathrm{min}$.

We initially conducted a catalyst screening using H-ZSM-5, HUSY, beta zeolites and Mn-P-ZSM-5 (Fig. S3). No reaction occurred at $300{ }^{\circ} \mathrm{C}$ or below. $350{ }^{\circ} \mathrm{C}$ was the minimum temperature required to have any activity. At $375^{\circ} \mathrm{C}$, the activity follows the order: H-ZSM-5 $\approx$ HUSY > Mn-P-ZSM- 5 > beta zeolite, while H-ZSM-5 provided the highest selectivity towards phenol (Fig. S3). Based on previous studies on de-alkylation reaction of alkylbenzenes $[47,48]$, the reaction occurs after substrate diffusion into the zeolite pores, where Brønsted acid sites lead to the formation of an arenium ion, followed by de-alkylation to form alkene and phenol. The propyl cation will donate a proton to the zeolite to afford propylene, and regenerate the active sites. H-ZSM-5 has the ideal combination of acidity and pore size, and therefore gave the best performance in propylphenol de-alkylation.

H-ZSM-5 $\left(\mathrm{SiO}_{2} / \mathrm{Al}_{2} \mathrm{O}_{3}=25\right)$ was selected to perform condition optimization. First, the influence of the $W / F$ was studied. Water was co-fed in the system as it plays a role by desorbing phenol from the zeolite therefore inhibiting catalyst deactivation [4]. The reaction is relatively slow and $W / F$ appears to be a critical factor to determine conversion and yield. At $W / F=0.5$ h, merely $20 \%$ substrate conversion was achieved, which sharply increased to $40 \%$ and $72 \%$, respectively, when $\mathrm{W} / \mathrm{F}$ increased to 0.75 and $1.0 \mathrm{~h}$. Next, pre-activation of H-ZSM-5 at $540{ }^{\circ} \mathrm{C}$ was tested, but there was no substantial change in reactivity.

The H-ZSM-5 catalyst was continuously evaluated for a period of $4 \mathrm{~h}$. A steady decrease of both activity and selectivity was observed. After $4 \mathrm{~h}$, substrate conversion dropped from $>90 \%$ to ca. $60 \%$, while the selectivity dropped to a less extent, from ca. $90 \%$ to $80 \%$. The color of spent catalyst was brown instead of white, indicative of carbon deposition. Several char- acterization techniques were employed to further understand the deactivation of zeolite catalyst. During TGA measurement, the brown H-ZSM-5 spent catalyst turned white again after completion of the analysis, indicating the removal of carbon deposit. Two distinct peaks can be observed at around 220 and $420{ }^{\circ} \mathrm{C}$, respectively. The first peak can be attributed to the burning of light coke (small to medium chain alkanes, aromatics) and chemisorbed molecules. The second one at higher temperature could represent the burning of heavier coke (peak approximately at the same temperature than carbon black burning (Fig. 3(a)). A total weight loss of $20 \%$ was observed for the entire process. FT-IR analysis was conducted to compare the fresh catalyst and the spent catalyst, but only peaks that correspond to the zeolite were present [51]. FT-IR analysis demonstrated that the zeolite structure remained intact after the reaction. From these data, it appears that the deactivation of H-ZSM-5 is mainly due to formation of coke within the micropores, due to secondary reactions or deposition of substrates on the surface. As known from the literature, coke formation affects the activity of zeolites by poisoning or blocking the access to the active Brønsted acid sites [50]. Indeed, the reactivity of H-ZSM- 5 could be simply recovered by activation at $400{ }^{\circ} \mathrm{C}$ in air for $1 \mathrm{~h}$ (data not shown).

\subsection{Combination of HDO and de-alkylation reactions}

After exploration of suitable parameters for both hydro-demethoxylation and de-alkylation reactions, we recognized the possibility of combining the two steps into a single-step to trim lignin derived monomers directly into phenol, since the two reaction has similar working temperature, pressure, and $W / F$ values. The single-step transformation requires 

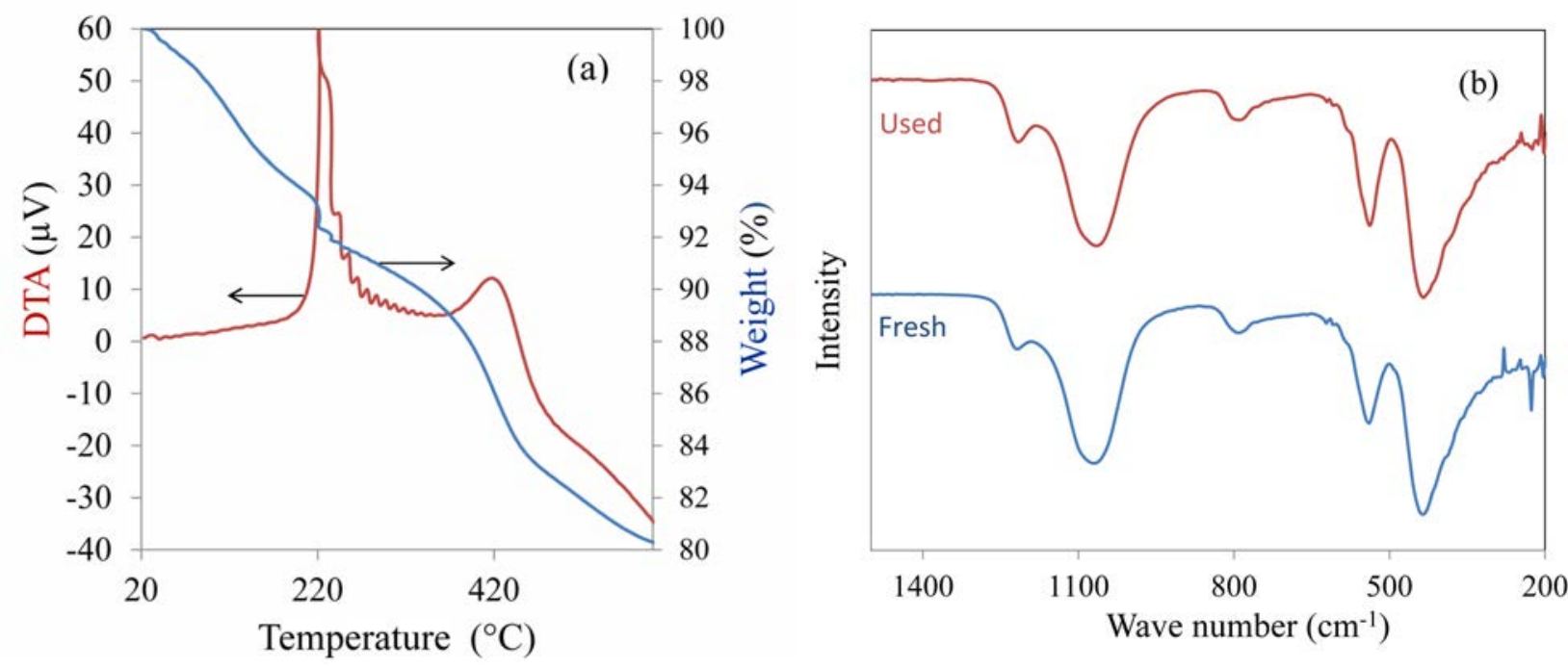

Fig. 3. (a) DTA and TGA of spent H-ZSM-5 catalyst; (b) FT-IR spectra of fresh and spent H-ZSM-5 catalysts.

substrate undergoing reactions on metal and zeolite catalyst sequentially, and therefore how to place the two catalysts in the reactor is a key factor.

Four configurations were evaluated (Fig. $4(\mathrm{a})$ ) at $375^{\circ} \mathrm{C}$, including (A) placing the Pt/C catalyst on the top and H-ZSM-5 in the bottom; (B) splitting Pt/C and H-ZSM-5 into three portions, where for each portion Pt/C and H-ZSM-5 were alternately packed and separated by silica wool; (C) physical mixture of Pt/C and H-ZSM-5; and (D) ball-milled mixture of the two catalysts. Indeed, the way that the two catalysts mix exhibited a profound influence on reactivity. Physically mixed Pt/C and H-ZSM-5 was the best, reaching $99 \%$ conversion and $66 \%$ selectivity, suggesting the benefit of placing the two catalysts in close contact. The main side products as identified by GC-MS include p-xylene, 3-propylphenol, anisole and 4-methyl phenol (Fig. S4). The existence of these chemicals highlight the non-quantitative selectivity is due to the incomplete cleavage of both methoxyl and alkyl chains, and the re-alkylation reaction between phenol and alkene. Ball-milled catalysts were the least active. This is mainly because the crystal structure of zeolite<smiles>CCCc1ccc(O)c(OC)c1</smiles>

(a)
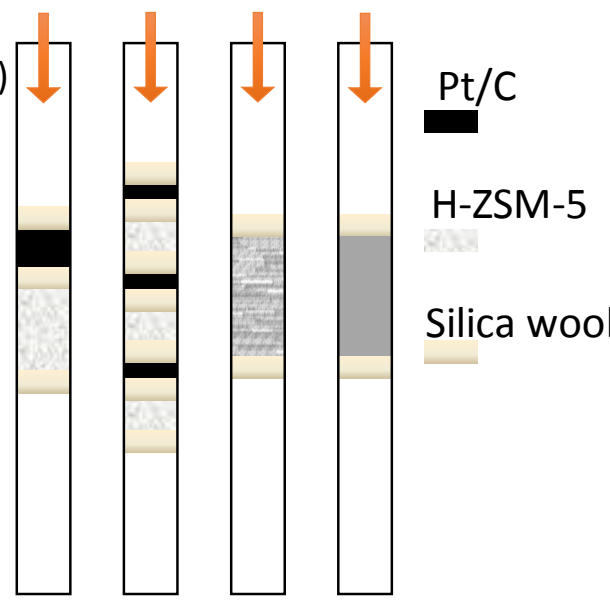

A
B

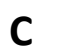

D

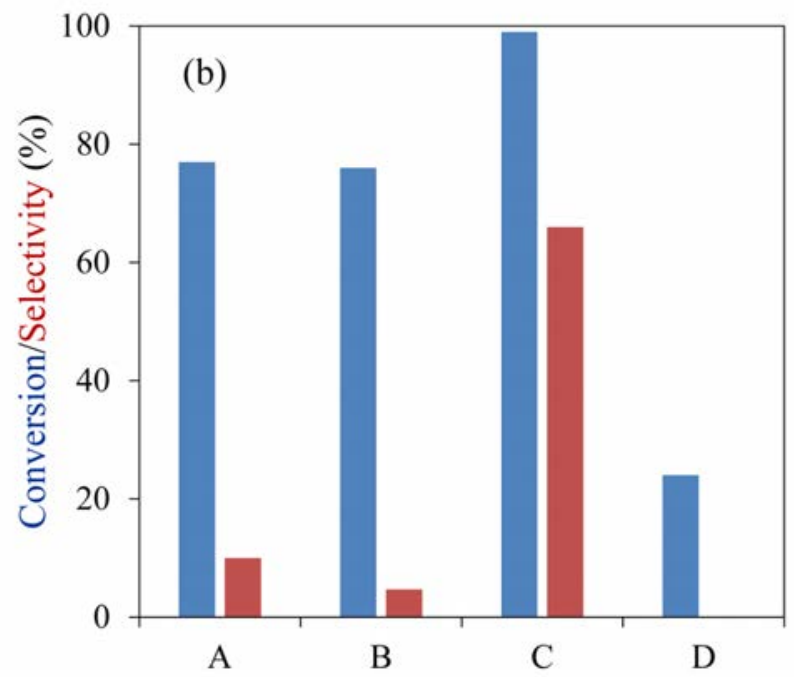

Fig. 4. (a) Schematic representation of the four configurations of the two catalysts in the reaction tube. (A) Pt/C packed on the top of H-ZSM-5, separated by silica wool. (B) Pt/C and H-ZSM-5 alternatively packed and separated by silica wool with three double-layers in total. (C) Physical-mix of the two catalysts. (D) Ball-milling of the two catalyst. (b) One step conversion of 2-methoxy-4-propylphenol into phenol with 4 catalysts' configurations. Reaction conditions: H-ZSM-5 $300 \mathrm{mg}$, Pt/C $50 \mathrm{mg}, 375^{\circ} \mathrm{C}$, 2-methoxy-4-propylphenol injection rate $240 \mu \mathrm{L} / \mathrm{h}$, water injection rate $240 \mu \mathrm{L} / \mathrm{h}, \mathrm{H}_{2}$ flow rate $10 \mathrm{~mL} / \mathrm{min}$. The data shown above are based on GC analysis of the sample collected on stream for $1 \mathrm{~h}$ from the second hour onwards. 


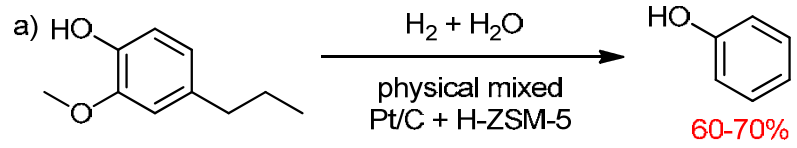

b)

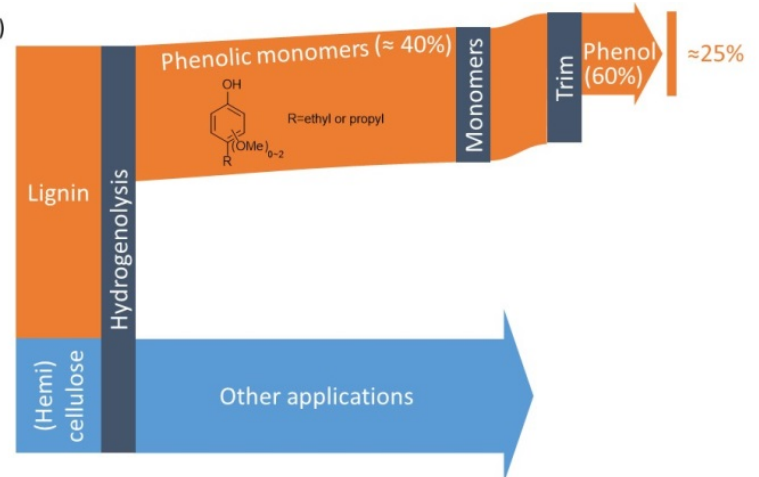

Scheme 2. (a) Overview of the single-step transformation of 4-propylguaiacol to phenol. (b) proposed whole utilization of woody biomass in which lignin is mainly converted into phenol.

was damaged by mechanical force, which is not uncommon when treating crystalline materials with ball-milling.

Physical mixtures of Pt/C and H-ZSM-5 at other temperatures $\left(325\right.$ and $\left.400^{\circ} \mathrm{C}\right)$, as well as Pt/C combined with HUSY or Mn-P-ZSM-5, were further tested to confirm that the data presented in Fig. 4(b), C provided the highest yield of phenol from 2-methoxy-4-propylphenol. Notably, the first step, i.e., hydro-demethoxylation over $\mathrm{Pt} / \mathrm{C}$ does not require water vapor while the second de-alkylation step over zeolite does. Considering that Pt/C catalyst is less affected by water (Fig. S6) than zeolite without water, co-feed of water vapour is beneficial for a high yield of phenol.

Success in trimming lignin monomers to phenol prompts us to propose a strategy to valorize wood for value-added chemicals. Woody biomass could be first converted into a mixture of phenolic monomers in ca. $40 \%$ yield via hydrogenolysis [68] and then following the single-step trimming chemistry shown in this work, $>60 \%$ of phenol would be obtained either via a two-step or a one-step approach, giving a combined yield of ca. $25 \%$ from native lignin. Methanol and alkenes (in particular propylene) as the major side products are also valuable. The hemicellulose and cellulose fraction or derivatives could be further upgraded following fermentation or chemical transformations.

\section{Conclusions}

In summary, we have established an effective way to convert lignin derived monomers into phenol, via hydro-demethoxylation and de-alkylation reactions. $\mathrm{Pt} / \mathrm{C}$ is the best catalyst for hydro-demethoxylation, presumably due to the strong interaction of carbon to the substrate, while H-ZSM-5 is most effective in de-alkylation. Notably, the two reactions are able to occur in a single-step by physical mixing the two catalysts, affording phenol in over $60 \%$ yield directly from 2-methoxy-4-propylphenol, which has not been achieved before. By combining with lignin depolymerization that has been extensively studied in the past decade, the process has the potential to upgrade lignin into phenol in a remarkable $25 \%$ yield (lignin basis). The current study helps to address a long standing challenge in lignin valorization, i.e., the depolymerized lignin is most often a complex mixture of phenolics whose transformation into a pure high value chemical is non-trivial. A limitation of the present work is the deactivation of catalyst in the de-alkylation reaction. Identification of a new support for Pt is underdoing in the laboratary, so that catalyst regeneration could be achieved simply by thermal treating in air.

\section{Acknowledgments}

We thank the Ministry of Education in Singapore Tier-1 (R-279-000-479-112) and Tier-2 (R-279-000-462-112) projects for the financial support.

\section{References}

[1] K. Sanderson, Nature, 2011, 474, S12-S14.

[2] C. Li, X. Zhao, A. Wang, G. W. Huber, T. Zhang, Chem. Rev., 2015, 115, 11559-11624.

[3] Y. Shao, Q. Xia, L. Dong, X. Liu, X. Han, S. F. Parker, Y. Cheng, L. L. Daemen, A. J. Ramirez-Cuesta, S. Yang, Y. Wang, Nat. Commun., 2017, 8, 16104.

[4] L. Shuai, M. T. Amiri, Y. M. Questell-Santiago, F. Héroguel, Y. Li, H. Kim, R. Meilan, C. Chapple, J. Ralph, J. S. Luterbacher, Science, 2016, 354, 329-333.

[5] Q. Xia, Z. Chen, Y. Shao, X. Gong, H. Wang, X. Liu, S. F. Parker, X. Han, S. Yang, Y. Wang, Nat. Commun., 2016, 7, 11162.

[6] M. Zaheer, R. Kempe, ACS Catal., 2015, 1675-1684.

[7] S. Van den Bosch, W. Schutyser, R. Vanholme, T. Driessen, S. F. Koelewijn, T. Renders, B. De Meester, W. J. J. Huijgen, W. Dehaen, C. M. Courtin, B. Lagrain, W. Boerjan, B. F. Sels, Energy Environ. Sci., 2015, 8, 1748-1763.

[8] V. Molinari, C. Giordano, M. Antonietti, D. Esposito, J. Am. Chem. Soc., 2014, 136, 1758-1761.

[9] K. Barta, G. R. Warner, E. S. Beach, P. T. Anastas, Green Chem., 2014, 16, 191-196.

[10] X. Huang, T. I. Korányi, M. D. Boot, E. J. M. Hensen, ChemSusChem, 2014, 7, 2051-2051.

[11] M. V. Galkin, S. Sawadjoon, V. Rohde, M. Dawange, J. S. M. Samec, ChemCatChem, 2014, 6, 179-184.

[12] R. Ma, W. Hao, X. Ma, Y. Tian, Y. Li, Angew. Chem. Int. Ed., 2014, 53, 7310-7315.

[13] P. Ferrini, R. Rinaldi, Angew. Chem. Int. Ed., 2014, 53, 8634-8639.

[14] J. Zhang, H. Asakura, J. van Rijn, J. Yang, P. Duchesne, B. Zhang, X. Chen, P. Zhang, M. Saeys, N. Yan, Green Chem., 2014, 16, 2432-2437.

[15] H. Konnerth, J. Zhang, D. Ma, M. H. G. Prechtl, N. Yan, Chem. Eng. Sci., 2015, 123, 155-163.

[16] J. Zhang, J. Teo, X. Chen, H. Asakura, T. Tanaka, K. Teramura, N. Yan, ACS Catal., 2014, 4, 1574-1583.

[17] Y. Hu, G. Jiang, G. Xu, X. Mu, Mol. Catal., 2018, 445, 316-326.

[18] Z. Luo, Z. Zheng, L. Li, Y. T. Cui, C. Zhao, ACS Catal., 2017, 7, 8304-8313.

[19] B. Ma, H. Cui, D. Wang, P. Wu, C. Zhao, Nanoscale, 2017, 9, 5986-5995.

[20] J. Chen, F. Lu, X. Si, X. Nie, J. Chen, R. Lu, J. Xu, ChemSusChem, 2016, 9, 3353-3360. 


\section{Graphical Abstract}

Chin. J. Catal., 2018, 39: 1445-1452 doi: 10.1016/S1872-2067(18)63132-8

\section{Single-step conversion of lignin monomers to phenol: Bridging the gap between lignin and high-value chemicals}

Jiaguang Zhang †, Loris Lombardo †, Gökalp Gözaydın, Paul J. Dyson, Ning Yan *

National University of Singapore, Singapore;

University of Lincoln, United Kingdom;

Ecole Polytechnique Fédérale de Lausanne (EPFL), Switzerland

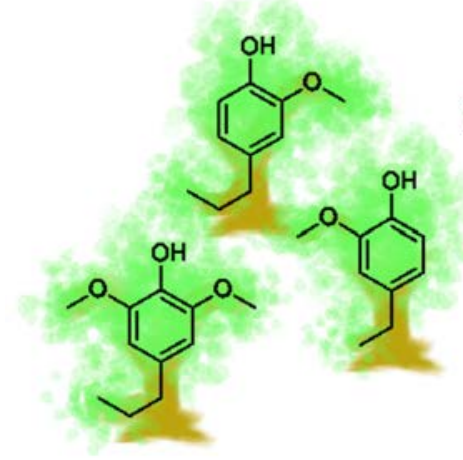

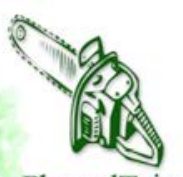

PhenolTrim Service

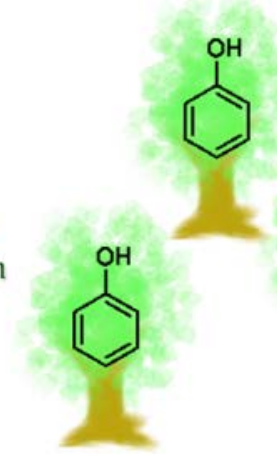

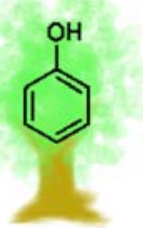

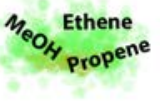

Lignin derived methoxyl alkyl substituted phenols were converted into phenol by hydro-demethoxylation and de-alkylation.

[21] H. Guo, B. Zhang, Z. Qi, C. Li, J. Ji, T. Dai, A. Wang, T. Zhang, ChemSusChem, 2017, 10, 523-532.

[22] C. S. Lancefield, O. S. Ojo, F. Tran, N. J. Westwood, Angew. Chem. Int. $E d ., 2015,54,258-262$.

[23] R. Ma, M. Guo, X. Zhang, ChemSusChem, 2014, 7, 412-415.

[24] Y. Gao, J. Zhang, X. Chen, D. Ma, N. Yan, ChemPlusChem, 2014, 79, 825-834.

[25] R. Lu, F. Lu, J. Chen, W. Yu, Q. Huang, J. Zhang, J. Xu, Angew. Chem. Int. Ed., 2016, 55, 249-253.

[26] W. Deng, H. Zhang, X. Wu, R. Li, Q. Zhang, Y. Wang, Green Chem., 2015, 17, 5009-5018.

[27] M. Wang, X. Zhang, H. Li, J. Lu, M. Liu, F. Wang, ACS Catal., 2018, 8, 1614-1620.

[28] P. J. Deuss, M. Scott, F. Tran, N. J. Westwood, J. G. de Vries, K. Barta, J. Am. Chem. Soc., 2015, 137, 7456-7467.

[29] T. D. H. Nguyen, M. Maschietti, T. Belkheiri, L. E. Åmand, H. Theliander, L. Vamling, L. Olausson, S. I. Andersson, J. Supercrit. Fluids, 2014, 86, 67-75.

[30] L. Yang, Y. Li, P. E. Savage, Ind. Eng. Chem. Res., 2014, 53, 2633-2639.

[31] J. A. Onwudili, P. T. Williams, Green Chem., 2014, 16, 4740-4748.

[32] A. Toledano, L. Serrano, J. Labidi, Fuel, 2014, 116, 617-624.

[33] J. Pan, J. Fu, S. Deng, X. Lu, Energy Fuels, 2013, 28, 1380-1386.

[34] J. Hu, D. Shen, S. Wu, H. Zhang, R. Xiao, Energy Fuels, 2014, 28, 4260-4266.

[35] S. Adhikari, V. Srinivasan, O. Fasina, Energy Fuels, 2014, 28, 4532-4538.

[36] G. T. Neumann, B. R. Pimentel, D. J. Rensel, J. C. Hicks, Catal. Sci. Technol., 2014, 4, 3953-3963.

[37] G. Jiang, Y. Hu, G. Xu, X. Mu, H. Liu, ACS Sustain. Chem. Eng., 2018, 6, 5772-5783.

[38] J. D. Nguyen, B. S. Matsuura, C. R. J. Stephenson, J. Am. Chem. Soc., 2013, 136, 1218-1221.

[39] H. Liu, H. Li, J. Lu, S. Zeng, M. Wang, N. Luo, S. Xu, F. Wang, ACS
Catal., 2018, 8, 4761-4771.

[40] N. Luo, M. Wang, H. Li, J. Zhang, H. Liu, F. Wang, ACS Catal., 2016, 6, 7716-7721.

[41] D. Shao, J. Liang, X. Cui, H. Xu, W. Yan, Chem. Eng. J., 2014, 244, 288-295.

[42] L. T. Mika, E. Cséfalvay, Á. Németh, Chem. Rev., 2018, 118, 505-613.

[43] N. Yan, X. Chen, Nature, 2015, 524, 155-157.

[44] J. G. Linger, D. R. Vardon, M. T. Guarnieri, E. M. Karp, G. B. Hunsinger, M. A. Franden, C. W. Johnson, G. Chupka, T. J. Strathmann, P. T. Pienkos, G. T. Beckham, Proc. Natl. Acad. Sci. USA, 2014, 111, 12013-12018.

[45] J. Sun, A. M. Karim, H. Zhang, L. Kovarik, X. S. Li, A. J. Hensley, J. S. McEwen, Y. Wang, J. Catal., 2013, 306, 47-57.

[46] T. Omotoso, S. Boonyasuwat, S. P. Crossley, Green Chem., 2014, 16, 645-652.

[47] T. Prasomsri, M. Shetty, K. Murugappan, Y. Roman-Leshkov, Energy Environ. Sci., 2014, 7, 2660-2669.

[48] A. L. Jongerius, R. W. Gosselink, J. Dijkstra, J. H. Bitter, P. C. A. Bruijnincx, B. M. Weckhuysen, ChemCatChem, 2013, 5, 2964-2972.

[49] N. Joshi, A. Lawal, Ind. Eng. Chem. Res., 2013, 52, 4049-4058.

[50] R. R. Barton, M. Carrier, C. Segura, J. L. G. Fierro, S. Park, H. H. Lamb, N. Escalona, S. W. Peretti, Appl. Catal. A, 2018, 562, 294-309.

[51] K. B. Jung, J. Lee, J. M. Ha, H. Lee, D. J. Suh, C. H. Jun, J. Jae, Catal. Today, 2018, 303, 191-199.

[52] L. Nie, B. Peng, X. Zhu, ChemCatChem, 2018, 10, 1064-1074.

[53] M. S. Jang, T. N. Phan, I. S. Chung, I. G. Lee, Y. K. Park, C. H. Ko, Res. Chem. Intermed., 2018, 44, 3723-3735.

[54] D. Verboekend, Y. Liao, W. Schutyser, B. F. Sels, Green Chem., 2016, 18, 297-306.

[55] K. Kase, T. Idai, K. Ishii, E. Takahashi, EP0296582 (A2), 1988. 
[56] Y. Liao, M. d'Halluin, E. Makshina, D. Verboekend, B. F. Sels, Appl. Catal. B, 2018, 234, 117-129.

[57] T. Sato, T. Adschiri, K. Arai, J. Anal. Appl. Pyrolysis, 2003, 70, 735-746.

[58] F. P. Daly, J. Catal., 1980, 61, 528-532.

[59] Y. Chen, K. Wang, J. Y. Yang, P. Q. Yuan, Z. M. Cheng, W. K. Yuan, Ind. Eng. Chem. Res., 2016, 55, 9578-9585.

[60] S. Kamiguchi, K. Kondo, M. Kodomari, T. Chihara, J. Catal., 2004, $223,54-63$

[61] D. Li, H. Zhang, M. Usman, Z. Li, L. Han, C. Li, S. Zhang, J. Renew. Sustain. Energy, 2014, 6, 033132/1-033132/15.

[62] M. Weber, M. Weber, M. Kleine-Boymann, Phenol, in: Ullmann's Encyclopedia of Industrial Chemistry, 2004.
[63] J. Wallace, S. Updated by, Phenol, in: Kirk-Othmer Encyclopedia of Chemical Technology, 2005.

[64] Z. Zhang, Y. Zhu, H. Asakura, B. Zhang, J. Zhang, M. Zhou, Y. Han, T. Tanaka, A. Wang, T. Zhang, N. Yan, Nat. Commun., 2017, 8, 16100.

[65] W. Deng, Y. Wang, S. Zhang, K. M. Gupta, M. J. Hülsey, H. Asakura, L. Liu, Y. Han, E. M. Karp, G. T. Beckham, P. J. Dyson, J. Jiang, T. Tanaka, Y. Wang, N. Yan, Proc. Natl. Acad. Sci. USA, 2018, 115, 5093-5098.

[66] B. Zhang, H. Asakura, J. Zhang, J. Zhang, S. De, N. Yan, Angew. Chem. Int. Ed., 2016, 55, 8319-8323.

[67] J. M. Serra, E. Guillon, A. Corma, J. Catal., 2004, 227, 459-469.

[68] N. Yan, C. Zhao, P. J. Dyson, C. Wang, L. T. Liu, Y. Kou, ChemSusChem, 2008, 1, 626-629.

\section{催化一步转化木质素单体为苯酚: 建立木质素到高附加值化学品的通道

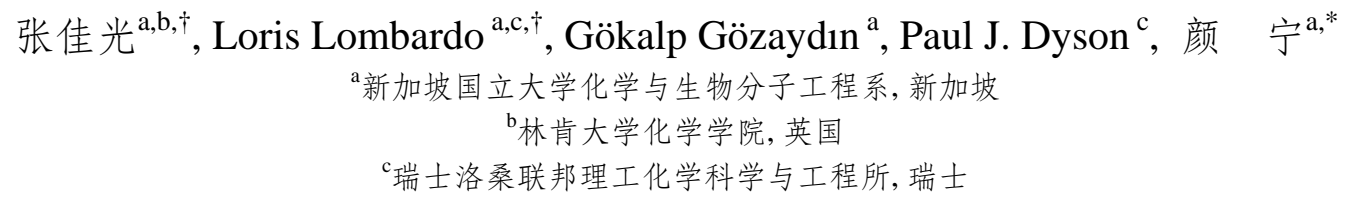

摘要: 木质素是地球上产量最大的芳香类有机高分子, 其有效转化利用在近年来备受关注. 催化降解木质素制备酚类单体 在过去十年取得了长足进步, 目前已开发出氢解、水解、热解、氧化、光解等一系列方法. 通过加氢脱氧法可以将木质素 的降解产物转化为烃类燃料, 但该过程耗氢量大, 并且芳香环在加氢气氛下被破坏. 另一个可能的应用是将木质素衍生物 进一步转化为高附加值的芳香族化合物, 但解聚产物成分复杂, 成为木质素高效转化为单一高附加值化学品的瓶颈.

在加氢条件下, 木质素解聚产物主要为酚类混合物, 多在羟基临位带有一至两个甲氧基, 并在对位带有C2或C3的取代 基(多为烷基). 针对这一结构特点, 我们设计了新反应路径, 通过分别去除甲氧基和烷基得到苯酚. 该过程保留了苯酚的基 本结构而将其他取代基去除, 原理上可以有效的将木质素降解的混合物转化为单一产物苯酚. 通过催化剂的篮选和优化, $\mathrm{Pt} / \mathrm{C}$ 催化剂对脱甲氧基显示出最好的活性和选择性, 在 $400{ }^{\circ} \mathrm{C}$, 常压下脱除效率 $>80 \%$. 在流动气氛下连续工作 $4 \mathrm{~h}, \mathrm{Pt} / \mathrm{C}$ 催 化剂无失活迹象. H-ZSM-5 为最有效的脱烷基催化剂, 最优效率 $83 \%$ 左右. H-ZSM-5在反应过程中逐渐失活. 通过热重差 热及红外光谱分析, 失活主要原因为积碳. 在 $400{ }^{\circ} \mathrm{C}$ 空气中煅烧后, 催化剂可以再生.

通过简单的物理混合, Pt/C和H-ZSM-5一步将木质素单体转化为 $60 \%$ 的苯酚, 显示了该方法直接转化木质素到高附加 值苯酚的巨大潜力. 这是同时将木质素中甲氧基、烷基选择性脱除的首例报道. 经过估算, 从原生木质素出发, 通过加氢解 聚, 耦合本文开发的一步脱甲氧基、烷基路径, 可将木质素转化为约 $25 \%$ 的苯酚. 木质素中的甲氧基、烷基将分别转化为甲 醇和烯烃, 提高了木质素碳资源的利用效率.

关键词: 木质素; 苯酚; 分子筛催化剂; 脱甲氧基; 脱烷基

收稿日期: 2018-06-28. 接受日期: 2018-07-04. 出版日期: 2018-09-05.

*通讯联系人. 电子信箱: ning.yan@nus.edu.sg

†共同第一作者.

基金来源：新加坡教育部资助项目(R-279-000-479-112, R-279-000-462-112).

本文的电子版全文由Elsevier出版社在ScienceDirect上出版(http://www.sciencedirect.com/science/journal/18722067). 